\title{
INTERPOLATED ALTITUDINAL SPECIES RICHNESS IN ARGHAKHACHI DISTRICT OF NEPAL
}

\author{
Babu Ram Nepali ${ }^{1,2}$, John Skartveit ${ }^{3}$, Chitra Bahadur Baniya ${ }^{1 *}$ \\ ${ }^{I}$ Central Department of Botany, Tribhuvan University, Kirtipur, Nepal \\ ${ }^{2}$ Butwal Multiple Campus, Tribhuvan University, Butwal, Nepal \\ ${ }^{3}$ University College, Norsk Laerer Akademi (NLA), Bergen, Norway \\ *Corresponding author: cbbaniya@gmail.com; Orcid.org: 0000-0002-8746-7601
}

(Received: November 27, 2019; Revised: February 27, 2020; Re-revised: April 27, 2020; Accepted: April 30, 2020)

\begin{abstract}
The magnitude of climatic variables over space and time determines the altitudinal variation of species richness. The present study has been carried out to determine the vascular plant species richness patterns along with altitude in the Arghakhanchi district $\left(27^{\circ} 45^{\prime}\right.$ to $28^{\circ} 06^{\prime} \mathrm{N}$ and $80^{\circ} 45^{\prime}$ to $\left.83^{\circ} 23^{\prime} \mathrm{E}\right)$, West Nepal. The published literature related to the altitudinal distribution of vascular plant species in Arghakhanchi district was collected and enlisted a total of 597 species. The altitudinal range of the Arghakhanchi district was 200-2300 meters above sea level (masl) which was divided equally into 21 bands of $100 \mathrm{~m}$ each. The total number of vascular species that occurred at each $100 \mathrm{~m}$ contour elevation was considered as the species richness. The objective of this study was to find the vascular plant species richness pattern in Arghakhanchi district concerning altitude and climatic variables. The generalized linear model (GLM) was applied to the total species richness against altitude, annual mean temperature (AMT), and mean annual rainfall (MAR). Total vascular species richness showed a statistically significant unimodal pattern with a maximum richness of 471 species at 1300 masl $\left(r^{2}=0.91 ; p<0.001\right)$. Likewise, gymnosperm, dicot, monocot, and pteridophyte species richness showed a highly significant unimodal altitudinal richness pattern. Altitudes of modeled maximum species richness were found varied according to the taxa.
\end{abstract}

Keywords: Climate, Contour elevation, GLM, Linear, Unimodal

\section{INTRODUCTION}

Altitudinal variation in species richness is clearly expressed by area (Wang et al., 2007), disparity of temperature and rainfall (Stevens \& Fox, 1991; Khan \& Ahmed, 2015), complex topography (Grytnes, 2003), aspect (Sharma et al. 2014), and soil composition (Dölarslan et al., 2017). The relationship between altitude and species richness shows three types of patterns: monotonically increasing, decreasing, and hump-shaped (Rahbek, 1995; Song \& Cao, 2017). More than $50 \%$ of researches related to altitudinal richness showed a unimodal pattern with high richness at an intermediate altitude (Rahbek, 1995; Oommen \& Shankar, 2005). There are numerous studies on species richness in Nepal which reported hump-shaped patterns with maximum richness at mid altitudes (Grytnes \& Vetaas, 2002; Bhattarai et al., 2004; Grau et al., 2007; Baniya et al., 2010). This hump-shaped pattern might not be prominent, particularly for small grain sizes and along incomplete gradients (Rahbek, 2005).

Mountains, an ideal natural system, provide gradients of climate and other environmental variables (Ghazal, 2015), harbor number of species (Gaston, 2000; Khan \& Ahmed, 2015) and environment to explore drivers determining species richness patterns (Körner, 2007) due to wider altitudinal range and complex topography at a short space. Stevens (1989), in "seasonal variability hypothesis" indicated that greater the seasonal temperature variations at high altitudes higher the species tolerant to greater climatic disparities. Biodiversity is not homogeneously dispersed across the earth (Khan et al., 2016). The prime factors such as altitudinal gradients, aspects and the physical environment (Korner, 2000; Sharma et al., 2014), climate, productivity, anthropogenic influences, evolutionary history, physiological traits and biotic interactions (Webb \& Gaston, 2003; Zhang et al., 2016) modify local microclimate and determine spatial and temporal distribution, abundance and richness patterns of organisms.

Species richness is the simplest and most frequently used (Brown et al., 2007), predictable and fundamental measure of the community at both local and regional levels of diversity (Gotelli \& Colwell, 2001). The height, diameter, and density of the species differed along the altitudinal gradient and showed a species-specific trend (Rana et al., 2016). The distribution range of species and species richness pattern is changeable concerning time and space (Gillman \& Wright, 2006). Species richness pattern appears as a combined picture of many ecological variables. The altitudinal range is the most important variable among all models at different scales which shapes patterns (Xu et al., 2017).

The altitude itself represents a combination of other topographical factors such as aspect and slope (Holland \& 
Steyn, 1975), climatic variables like temperature, rainfall, etc. and edaphic properties (Ramsay \& Oxley, 1997). Generally, the area decreases with the increase of altitude in the Himalaya region. Larger the area greater will be the number of species occupied (Lomolino, 2001) due to availability of more habitats or space, biogeographical provinces (Williams, 1964), and greater heterogeneity (Wills et al., 2005). According to Bhattarai (2017), broadscale explanatory variables cannot detect richness patterns at the finer scales and vice versa. Monotonic, unimodal, or multimodal patterns are common at local scales whereas unimodal pattern is favored for regional scales when multiple local replicates are aggregated (Oommen \& Shanker, 2005). Even within the same mountain, organisms inhabiting different slopes may possess distinct diversity patterns and the underlying mechanisms (Shuai et al., 2017).

Climatic factors vary with altitude, influence species richness patterns (Bhattarai, 2017). The physiological activities as productivity and life-form diversity are determined by the interactions between temperature and precipitation (O'Brien, 2002). Measurable changes in climate may occur only at distances greater than $100 \mathrm{~km}$ (O'Brien et al., 1998), but environmental variation appears along the $100 \mathrm{~m}$ altitudinal differences (Bhattarai et al. 2004).

Variation in species richness with altitude either connected with the rate of change of eco-physiological processes or due to the change in temperature and productivity (Rahbek, 1995). Precipitation is relatively a complex gradient (Adler \& Levine, 2007; Lomolino, 2001), that showed a spatial variation i.e., enhanced in some regions and decreased in some other mountainous regions. The altitudinal pattern in species richness has opened up ample options to find out the general mechanisms responsible for the distribution of biodiversity (Grytnes \& McCain, 2007).

Nepal is a part of the central Himalayas where many unique biodiversity areas are yet to explore and proper conservation may be necessary. Arghakhanchi is one of the 77 districts, lies in the fifth province in Nepal and the high biodiversity zone of the mid-mountain region. The Humpbacked species richness-curve is a contingent rule for Community Ecology (Graham \& Duda, 2011) which may be based on primary or secondary data. Different environmental factors act as the main driver of species richness at large and small areas (Vetaas \& Ferrer-Castan, 2008). Thus this study puts the hypothesis that vascular species richness follows the unimodal pattern with altitude as well as climatic variables.

The main aim of this study was to determine the altitudinal species richness pattern of vascular and its derivatives richness pattern and relation with climatic variables.

\section{MATERIALS AND METHODS}

\section{Study area}

Arghakhanchi, one of the beautiful hilly districts, is located in Providence No. 5, west part of Nepal. It ranges from $27^{\circ} 45^{\prime}$ to $28^{\circ} 06^{\prime} \mathrm{N}$ latitude and $80^{\circ} 45^{\prime}$ to $83^{\circ} 23^{\prime} \mathrm{E}$ longitudes (Map. 1). It covers an area of $1193 \mathrm{~km}^{2}$ and a population of 197,632 (CBS, 2012). About $68 \%$ of this district lies within the Mahabharat range and rest in the Siwalik hills. The altitude of this district ranges from 240 to 2515 masl (AEPC, 2016)). Physiographically, this district has four zones: lower tropical (less than 300 mas covers $0.2 \%$ ), upper tropical (300-1000 masl covers 51 $\%)$, subtropical (1000-2000 masl covers $49 \%$ ) and temperate zone (above than 2000 masl covers $0.2 \%$ ) (CBS, 2012). The average maximum and minimum temperatures range are between $25-27^{\circ} \mathrm{C}$ in May-July and 5-7 ${ }^{\circ} \mathrm{C}$ in January (DHM, 2017). The average annual rainfall of this district remains around $1750 \mathrm{~mm}$ (MOAC/FAO, 2011). According to MOAC (2011), out of the total 119,300 ha land of the district, cultivable land occupies 45,712 ha (38\%), forested land occupies 66,800 ha $(56 \%)$, river and ponds occupy 5768 ha $(4.8 \%)$ and the residential area covers 1020 ha $(0.85 \%)$.

Lowlands, the southern part of Arghakhanchi, consists of the lower tropical forest of Shorea robusta, Dalbergia sissoo, Lagestroemia parviflora, Terminalia alata, etc. Churia sal forest lies between 300-1000 masl, dominated by $S$. robusta, T. alata, Cassia fistula, Bauhinia variegata, etc. In the middle belt, hill Sal forest is present with Schima wallichii, Syzygium cumini, Pinus roxburghii, and Pyrus pashia. In the northern aspect (below 1000 to 1500 masl), the broad-leaved forest ( Diospyrus malabarica, Rhododendron arboreum, S. wallichii, Catonopsis indica) is intermixed with $P$. roxburghii and $S$. robusta. Between 1500-2000 masl, broad-leaved forest ( $R$. arboreum, $S$ wallichii, $P$. roxburghii, Myrica esculenta) is present. The uppermost region (above than 2000 masl) in this district, the Rhododendron - Quercus-Maesa mixed forest is present which is dominated by $R$. arboreum, $Q$. semecarpifolia, Q. glauca, M. esculenta, Zanthoxylum armatum with bushes of Maesa chisia, etc (Panthi, 2005).

\section{Study design and data collection}

This study analyzed plant and climatic data collected from secondary sources described herein. Altitudinal distribution range of plants in the Arghakhanchi district was derived from different literature (Acharya et al. 2015; Fraser-Jenkins et al., 2015; Fraser-Jenkin \& Kandel, 2019; Panthi, 2005; Panthi \& Chaudhary, 2002; Pokhrel 2013; Poudel et al., 2010). The altitudinal range (2002300 masl) of Arghakhanchi district where plants were reported from was divided equally into 21 bands each with 100 masl intervals each. The species present in each 100 masl contour was considered as the species richness. 
Similarly, species richness was categorized into dicot, monocot, gymnosperm, and fern or pteridophyte species richness. This is a macro-scale study that covered an entire altitudinal range of Arghakhanchi district.

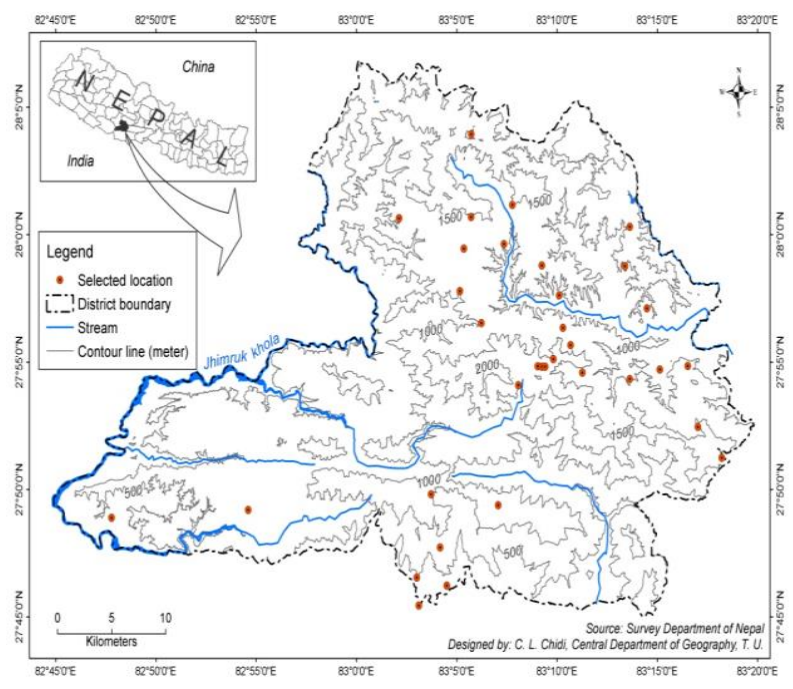

Map 1. Arghakhanchi district with botanically explored sites

Annual mean temperature (AMT) and mean annual rainfall (MAR) data for Arghakhanchi district and surrounding areas obtained through published literature (MoAC, 2011; AEPC, 2016; DHM, 2017) were utilized in this study (Table 1). AMT per 100 altitudinal zone in this study was estimated after significant linear regression model $\left(R^{2}=0.99 ; p<0.05\right)$ at a lapse rate of $0.5^{\circ} \mathrm{C} / 100$ $\mathrm{m}$ (Bhattarai et al., 2004). Rainfall was not a simple linear function of altitude, therefore a cubic smooth spline with 4 degrees of freedom was applied through the GAM model (Guisan et al., 2002) to estimate total annual rainfall at each $100 \mathrm{~m}$ altitudinal bands.

\section{Data analysis}

The correlation among variables was estimated by using Pearson's Correlation method (Kassambara, 2018). The regression analysis of species richness against altitude was done by using the GLM (Hastie \& Pregibon, 1993). Likewise, regression analysis of species richness was done against climatic variables such as MAR and AMT. The quasipoisson family of error distribution was applied to remove overdispersion. All these analyses were done in R (R Core Team, 2019).

\section{RESULTS}

\section{Species richness of vascular plants}

A total number of 597 vascular plant species (belonging to 452 genera and 190 families) were recorded in Arghakhanchi district (Table 2). The dicots consisted of $83.9 \%$ species (157 families, 381 genera, and 501 species) while the monocot consisted of $13.9 \%$ (24 families, 62 genera and 83 species), gymnosperm consisted of $0.5 \%$ ( 2 families, 2 genera and 3 species), and pteridophytes (ferns) consisted of $1.7 \%$ species (7 families, 7 genera and 10 species) as summarized in Table 2.

Table 1. Climatic records of Arghakhanchi and surrounding areas from 1994-2013 AD (MoAC, 2011; AEPC, 2016; DHM, 2017)

\begin{tabular}{llllll}
\hline Place & $\begin{array}{l}\text { Alt } \\
(\mathrm{m})\end{array}$ & $\begin{array}{l}\text { Lat } \\
\left({ }^{\circ}\right)\end{array}$ & $\begin{array}{l}\text { Lon } \\
\left({ }^{\circ}\right)\end{array}$ & $\begin{array}{l}\text { Amt } \\
\left({ }^{\circ} \mathrm{C}\right)\end{array}$ & $\begin{array}{l}\text { Mar } \\
(\mathrm{mm})\end{array}$ \\
\hline Taulihawa & 94 & 27.33 & 83.04 & 24.3 & 1357 \\
Bhairahawa & 109 & 27.31 & 83.26 & 24.2 & 1630 \\
Patharkot & 200 & 27.46 & 83.03 & 23.5 & 1467 \\
Butwal & 205 & 27.42 & 83.28 & 24 & 2203 \\
Ghorai & 701 & 28.03 & 82.3 & 22.1 & 1572 \\
Tulsipur & 725 & 28.08 & 82.18 & 22.4 & 1650 \\
Bijuwar & 823 & 27.52 & 82.52 & 22.2 & 1272 \\
Tansen & 1201 & 27.52 & 83.32 & 18.4 & 1912 \\
Libang & 1270 & 28.18 & 82.38 & 18.7 & 1312 \\
Salyan Bazar & 1457 & 28.23 & 82.1 & 19.2 & 987 \\
Tamghas & 1530 & 28.04 & 83.15 & 17.5 & 1897 \\
Khanchikot & 1760 & 27.56 & 83.09 & 16.4 & 1775 \\
\hline * Alt- altitude, Lat- latitude, Lon- longitude, & Amt- annual mean \\
$\quad$ temperature; Mar- mean annual rainfall & &
\end{tabular}

Table 2. Taxonomic diversity of vascular plants in Arghakhanchi district

\begin{tabular}{lllllll}
\hline Taxa & \multicolumn{6}{c}{ Species richness } \\
& Herb & Shrub Tree & Climber & Fern Total \\
\hline Dicot & 188 & 125 & 138 & 50 & - & 501 \\
Monocot & 70 & 4 & 1 & 8 & - & 83 \\
Gymnosperm & - & - & 3 & - & - & 3 \\
Pteridophyte & - & - & - & - & 10 & 10 \\
Grand total & 258 & 129 & 142 & 58 & 10 & 597 \\
\hline
\end{tabular}

\section{Correlation among variables}

All vascular taxa showed positive but not significant relationship ( $r=0.11$ to $0.26, p<0.001$ ) with altitude Similar there was positive relationship between rainfall and vascular taxa except for monocot and gymnosperm (Table 3). But, the vascular taxa showed a negative and not significant relationship with temperature.

\section{Species richness pattern of vascular plants against altitude}

The species richness of vascular taxa (dicot, monocot, gymnosperm, and ferns) increased up to a certain altitude 
then declined afterward showing a unimodal distribution pattern, as indicated by a statistically significant secondorder model in GLM (Appendix 1). The total vascular species obtained the maximum modeled species 471
$\left(R^{2}=0.914\right.$ and $\left.\mathrm{p}<0.001\right)$ at peak elevation $1300 \mathrm{~m}($ Fig. 1a). Similarly, the richness of dicot taxa (Fig. 1b), monocot (Fig. 1c), Gymnosperm (Fig. 1d), and ferns (Fig. 1e) made a hump-shaped structure against altitude.

Table 3. Correlation among species richness, altitude, temperature, and rainfall $(p<0.001)$

\begin{tabular}{|l|l|l|l|l|l|l|l|l|}
\hline & Altitude & Temp & Rainfall & Gymno & Pterido & Monocot & Dicot & Total spp \\
\hline Altitude & 1 & - & - & - & - & - & - & - \\
\hline Temperature & -1 & 1 & - & - & - & - & - & - \\
\hline Rainfall & 0.8 & -0.8 & 1 & - & - & - & - & - \\
\hline Gymnosperm & 0.26 & -0.26 & 0.06 & 1 & - & - & - & - \\
\hline Pteridophytes & 0.23 & -0.23 & 0.12 & 0.89 & 1 & - & - & - \\
\hline Monocots & 0.11 & -0.11 & -0.02 & 0.9 & 0.96 & 1 & - & - \\
\hline Dicot & 0.2 & -0.2 & 0.11 & 0.86 & 0.98 & 0.96 & 1 & - \\
\hline Total species & 0.19 & -0.19 & 0.09 & 0.87 & 0.98 & 0.97 & 1 & 1 \\
\hline
\end{tabular}

Temp = temperature, Gymno = Gymnosperm, Pterido $=$ Pteridophytes, spp $=$ species
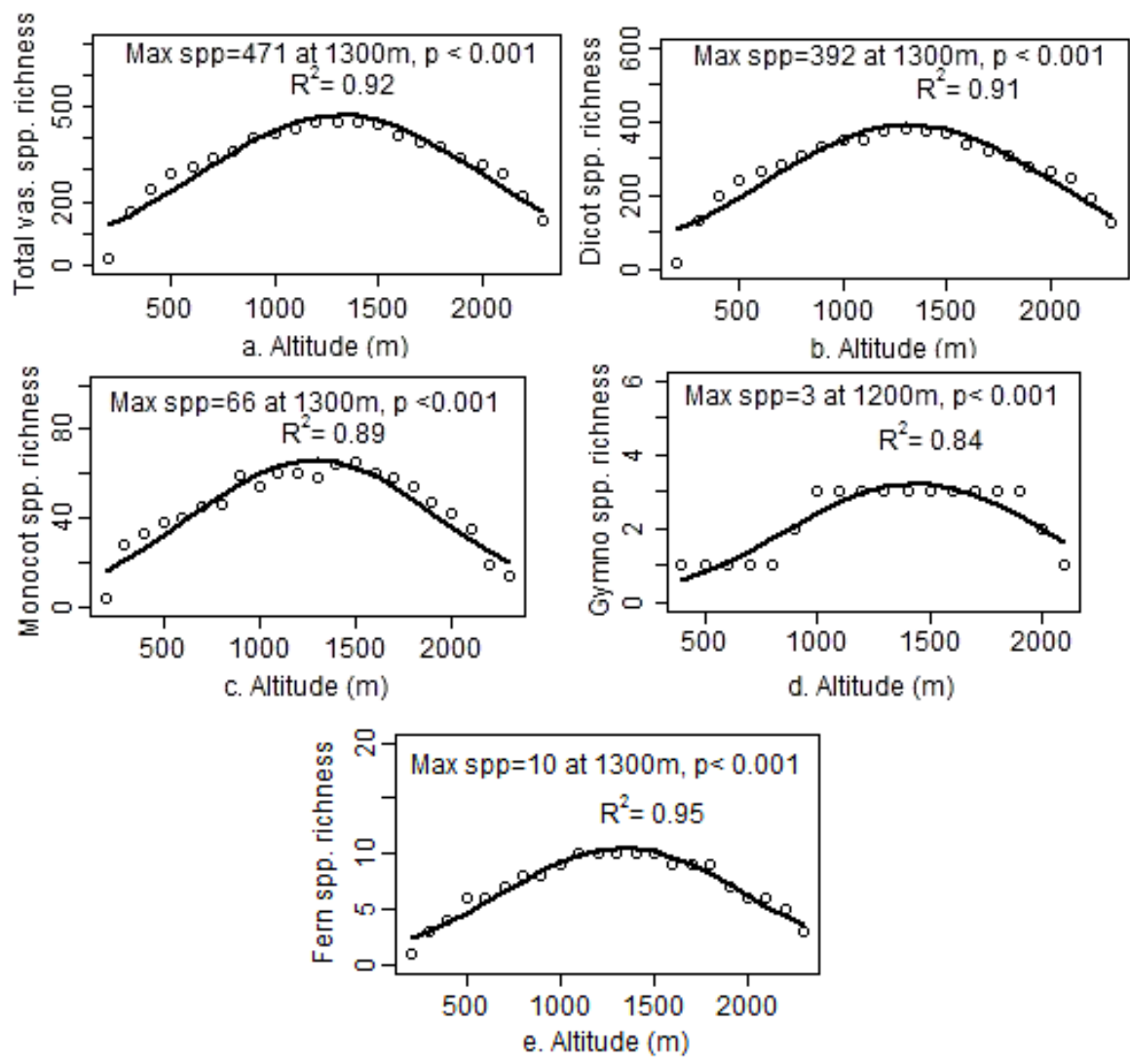

Fig. 1. Estimated response curves by GLM model, which portrays the relationship between altitude and species richness of (a) total vascular species (b) dicot (c) monocots (d) gymnosperm and (e) ferns

\section{Species richness pattern against climatic variables}

The richness pattern between vascular species and climatic variables (temperature and rainfall) was also unimodal, which was indicated by a statistically significant second-order term in GLM (Appendix 1). The species richness increased along with the annual mean temperature (AMT) and decreased after optimum value $18.2{ }^{\circ} \mathrm{C}$ (at $1300 \mathrm{~m}$ ) showing unimodal structure (Fig. 2a) bearing maximum modeled species $472\left(R^{2}=0.914, p<\right.$ $0.001)$. Similarly, the species richness showed unimodal 
with plateau structure with mean annual rainfall (MAR) as depicted in Fig. 2(b) with maximum modeled species 432 at optimum value $1805.4 \mathrm{~mm}$ (at $900 \mathrm{~m}, R^{2}=0.64$ and $p<$ 0.001).

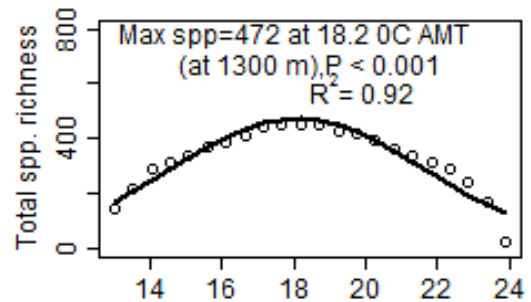

a. Annual Mean Temperature $\left({ }^{\circ} \mathrm{C}\right)$

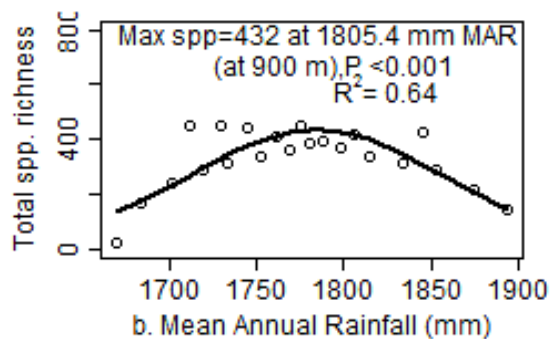

Fig. 2. Estimated response curves by the generalized linear model $(G L M)$, which portrays the relationship between total species richness and (a) annual mean temperature (AMT) and (b) mean annual rainfall (MAR)

\section{DISCUSSION}

\section{Species richness}

Arghakhanchi is a biodiversity-rich district in Nepal due to the occurrence of 597 vascular species belonging to 452 genera and 190 families. This district covers $0.81 \%$ of the total land area of Nepal (AEPC, 2016). It occupies 11.06 $\%$ of the total flowering species of Nepal (5309 species as reported by Rajbhandari et al., 2017) and $1.87 \%$ of the total pteridophytes (534 species reported by FraserJenkins et al., 2015) in Nepal. However, Panthi \& Chaudhary (2002) reported a total of 501 flowering plants from the Arghakhachi district. This number does not include the pteridophyte species. He increased the number of flowering plants as well as pteridophyte and may represent an increasing number of exploration from this district as well as other parts of the country. Based on these species we can say that the Arghakhanchi district rich in biodiversity though it is small in area. The species dominated and confined here are mainly of tropical to temperate origin.

\section{Correlation among variables}

There was a weak positive correlation among species richness variables of vascular taxa with altitude. This correlation was strong among species richness themselves: Gymnosperm, Pteridophyte, and Monocot richness. The latter strong correlation among species would be the higher proportion of these species in the total richness. The result of empirical fern species richness and altitude (Jeyalatchagan et al., 2019) and interpolated plant species richness with altitude (Grytness \& Vetaas, 2002) was also found to be a positive relationship. The positive relationship between altitude and species richness may be due to an extend of altitude as well as a limit of the mountain. Since the altitudinal extent of Arghakhanchi was 200 to 2300 masl. Thus the positive relationship between altitude and richness was justified.

Similarly, rainfall showed a positive but temperature expressed a negative relation with species richness. Zhang et al. (2016) also found similar results that annual mean temperature (AMT) showed negative but rainfall showed a positive correlation against species richness at the temperate region of China. According to Sharma et al. (2009), altitude and climatic factors are the main regulating factors of distribution and show significant negative relation with species richness. The altitude itself represents a complex combination of related climatic variables with other environmental properties. Generally, environmental variables are measured at different units of scale. Each of these variables hardly shows a simple and direct linear relationship with species richness (Pitcher et al., 2012). This means species richness may show nonlinear pattern with environmental variables.

\section{Species richness pattern}

From this study a significant unimodal species richness pattern against altitude was found. Similar patterns were observed for vascular plants (Grytness \& Vetaas, 2002; Bhattarai \& Vetaas, 2006), Bryophytes (Grau et al., 2007), lichens (Baniya et al., 2010), herbaceous plants (Bhatta et al., 2018), and environmental variables (Pokharel et al., 2018), etc. in central Nepal. The general unimodal species richness pattern was justified. During interpolation, the species present in an altitudinal band may create an artificial decrease in species richness towards both ends of the altitudinal gradient (Grytness \& Vetaas, 2002). That may impose an artificial unimodal richness pattern. However, the altitudinal range of individual species in this study was beyond the extent of altitude of the landscape. Thus obtained unimodal richness pattern of this study is not an artifact. This result concludes that species richness of vascular plants has a unimodal pattern to altitude and climatic variables of the mountainous area, which was well portrayed by the fitted GLM.

In this study, greater number of species was present at 1200-1400 masl, which is less (1500 to 2500 for flowering plants and $1900 \mathrm{~m}$ for ferns) than overall Nepal (Grytnes \& Vetaas, 2002). According to Bhattarai \& Vetaas (2006), the range of species remains wider at midelevation and narrower at the gradient endpoints. Colwell 
\& Hunt (1994) explained that the mid-elevation peaks in species richness were formed by an increase of overlapping of species range towards the center of the domain. This helps to conclude that more or less midaltitude of the overall distribution range bear maximum species richness.

The unimodal pattern of species richness may also be connected to human disturbance as well as disturbance associated with other factors. Arghakhanchi falls under the middle mountain range where human dominance is generally more than in higher altitudes. Middle mountain provides lots of opportunities and has been providing diverse ecological services to human from ethnomedicines (Rai \& Singh, 2015) to several others (Bhandari et al., 2018). That may support a finding of a unimodal relationship with altitude.

The climatic variables (temperature and rainfall) for total species graphed characteristically showed a significant unimodal pattern. Bhattarai et al., (2004) found fern richness monotonically decreased towards higher (lowland) and lower (highland) values of the Potential Evapotranspiration (PET) gradient. The changes in temperature systematically alter the relationship between the biodiversity and ecosystem functioning via a temperature-driven shift in the strength of selection and complementary effects (Garcia et al., 2018).

Similarly, species richness showed more strong correlation with temperature than rainfall, which was supported by the previous study of Griffiths et al. (2013). Temperature and rainfall variation occurs due to the altitudinal difference of mountains as well. Precipitation, a relatively complex pattern (Lomolino, 2001), is enhanced in some regions and decreased in other areas in the mountainous region. It has a significant impact on the productivity and species richness of the community (Yan et al., 2015). The species richness of annuals, as well as perennial plants, may increase significantly with increasing annual and seasonal precipitation. Hence, Arghakhanchi lies relatively at the higher biodiversity zone in Nepal, favored by moderate disturbance, higher AMT, and MAR that support unimodal richness patterns.

The altitudinal distribution range was the most important predictor at all scales (Vetaas \& Ferrer-Castan, 2008). It was supported that low peak elevation (1200-1400 m) in this study was proportional to less altitudinal distribution range (200-2300 $\mathrm{m})$ of Arghakhanchi in comparison to overall Nepal ( 86 to $8848 \mathrm{~m}$ ). Thus it is similar in species richness pattern but numerically different in peak elevation having the highest number of species to overall Nepal. The range margins of species in the gradient are determined directly or indirectly by unsuitable extremes of climatic factors (Bhattarai et al., 2004) or geographical hard boundaries.

\section{CONCLUSION}

This study reported 597 vascular species in the Arghakhanchi district. The species richness showed a positive correlation with altitude and rainfall but a negative correlation with temperature. The species richness showed significant unimodal response with altitude, temperature, and rainfall. However, altitudes of the highest richness were found significantly different with taxa and less than the general pattern as purposed for Nepal.

\section{REFERENCES}

Acharya, R., Marasini, D., \& Acharya, D. P. (2015). Traditional knowledge on medicinal plants used for the treatment of domestic cattle in Dhikura village of Arghakhanchi district, Nepal. Advanced Journal of Medicinal Plants Research, 2 (1), 006-016.

Adler, P. B., \& Levine, J. M. (2007). Contrasting relationships between precipitation and species richness in space and time, Oikos. 116, 221-232.

AEPC (2016). District climate and energy plan of Arghakhanchi District. Alternative energy promotion center, National rural and renewable energy program, Khumaltar.

Baniya, C. B., Solhøy, T., Gauslaa, Y., \& Palmer, M. W. (2010). The elevation gradient of lichen species richness in Nepal. The Lichenologist, 42(1), 83-96.

Bhandari, A., Khadka, U., \& Kanel, K. (2018). Ecosystem services in the mid-hill forest of Western Nepal: A case study of Panchase protected forest. Journal of Institute of Science and Technology, 23(1), 10-17.

Bhatta, K. P., Grytnes, J. A., \& Vetaas, O. R. (2018). Scale sensitivity of the relationship between alpha and gamma diversity along an alpine elevation gradient in central Nepal. Journal of Biogeography, 45, 804-814.

Bhattarai, K. R. (2017). Variation of plant species richness at different spatial scales. Botanica Orientalis, 11, 49-62.

Bhattarai, K. R., \& Vetaas, O. R. (2006). Can Rapport's rule explain tree species richness along the Himalayan elevation gradient, Nepal? Diversity and Distribution, p. 6. https://doi.org/10.1111/j.13669516.2006.00244.x.

Bhattarai, K. R., Vetaas, O. R., \& Grytnes, J. A. (2004). Fern species richness along a central Himalayan elevation gradient, Nepal. Journal of Biogeography, 31, 398-400.

Brown, R. L., Jacobs, L. A., \& Peet, R. K. (2007). Species richness: small scale. Encyclopedia of Life Sciences. https://doi.org/10.1002/9780470015902.a0020488. 
CBS (2012). National Population and Housing Census 2011 (National Report). Government of Nepal, National Planning Commission Secretariat, Central Bureau of Statistics, Kathmandu, Nepal.

Colwell, K. R., \& Hurtt, G. C. (1994). Non-biological gradients in species and richness a spurious rapoport effect. The American Naturalist, 144(4), 570-595.

DHM, (2017). Observed Climate Trend Analysis in the Districts and Physiographic Regions of Nepal (1971-2014). Department of Hydrology and Meteorology, Kathmandu, p. 93.

Dölarslan, M., Gül, E., \& Erşahin, S. (2017). Relationship between soil properties and plant diversity in a semiarid grassland. Turkish Journal of AgricultureFood Science and Technology, 5(7), 800-806.

Fraser-Jenkins, C. R., Kandel, D. R., \& Pariyar, S. (2015). Ferns and Fern-allies of Nepal. Department of Plant Resources, National Herbarium and Plant Resources, Ministry of Forests and Soil Conservation, Nepal, pp. 492.

Fraser-Jenkins, C. R., \& Kandel, D. R. (2019). Ferns and Fern-allies of Nepal. National Herbarium and Plant Resources, Department of Plant Resources, Ministry of Forests and Soil Conservation, Nepal, pp. 446.

FRSC (1994). Forest Resources of Arghakhanchi District. Forest Research and Survey Center, Ministry of Forest and Soil Conservation, Forest Resource Information System Project /FINNIDA, Kathmandu, Nepal, Publication No.: 61, p. 22.

Garcia, F. C., Bestion, E., Warfield, R., \& YvonDurocher, G. (2018). Changes in temperature alter the relationship between biodiversity and ecosystem functioning. Proceedings of the National Academy of Sciences, 115(43), 10989-10994.

Gaston, K. J. (2000). Global patterns in biodiversity. Nature, 405, 220-227.

Ghazal, A. M. F. (2015). Vegetation patterns and plant communities' distribution along an altitudinal gradient at Asir Mountain, southwest Saudi Arabia. Pakistan Journal of Botany, 47, 1377-1389.

Gillman, L. N., \& Wright, S. D. (2006). The influence of productivity on the species richness of plants: a critical assessment. Ecology, 87, 1234-1243.

Gotelli, N. J., \& Colwell, R. K. (2001). Quantifying biodiversity: procedures and pitfalls in the measurement and comparison of species richness, Ecology Letters, 4, 379-391.

Graham, J. H., \& Duda, J. J. (2011). The humpbacked species richness-curve: A contingent rule for community ecology. International Journal of
Ecology, 2011, pp.

https://doi.org/10.1155/2011/868426.

Grau, O., Grytnes, J.A., \& Birks, H. J. B. (2007). A comparison of altitudinal species richness patterns of bryophytes with other plant groups in Nepal, Central Himalaya. Journal of Biogeography, 34, 1907-1915.

Griffiths, D., McGonigle, C., \& Quinn, R. (2013). Climate and species richness patterns of freshwater fish in North America and Europe; Journal of Biogeography. 41(3), 452-463.

Grytness, J.A. (2003). Species richness patterns of vascular plants along seven altitudinal transects in Norway. Ecography, 26, 291-300.

Grytnes J. A., \& McCain C. M. (2007). Elevational trends in biodiversity. In: A. L. Simon (Ed.). Encyclopedia of Biodiversity (pp. 1-8). New York, USA: Elsevier.

Grytnes, J. A., \& Vetaas, O. R., (2002). Species richness and altitude: a comparison between null models and interpolated plant species richness along the Himalayan altitudinal gradient, Nepal. American Naturalist, 159, 294-304.

Guisan, A., Thomas, C., Edwards, Jr., \& Hastie, T. (2002). Generalized linear and generalized additive models in studies of species distributions: Setting the scene. Ecological modeling, 157(2-3), 89-100.

Hastie T. J., \& Pregibon, D. (1992). Generalized linear models. In: J. M. Chambers \& T. J. Hastie (Eds.), Statistical Models in S (pp. 195-247). Pacific Grove: Wadworth and Books/Cole.

Holland, P. G., \& Steyn, D. G. (1975). Vegetational responses to latitudinal variations in slope angle and aspect. Journal of Biogeography, 2, 179-183.

Jeyalatchagan, S. K., Ayyanar, M., \& Silambarasan, R. (2019). Pteridophyte species richness along elevation gradients in Kolli hills of the Eastern Ghats, India. Journal of Asia Pacific Biodiversity, 13, 92-106.

Kassambara, A. (2018). $R$ Graphics essentials for great data visualization. www.sthda.com/wiki/datavisualization.

Khan, S. M., \& Ahmad, H. (2015). Species diversity and use patterns of the alpine flora with special reference to climate change in the Naran, Pakistan. In: M. Öztürk, R. K. Hakeem, I. Faridah-Hanum, \& R. Efe (Eds.). Climate Change Impacts on High-Altitude Ecosystems (pp. 155-175). Switzerland: Springer International Publishing.

Korner, C. (2000). Why are there global gradients in species richness? Mountains might hold the answer. Trends in Ecology and Evolution, 15(12), 513-514. 
Korner, C. (2007). The use of altitude in ecological research. Trends in Ecology \& Evolution, 22 (11), 569-574.

Lomolino, M. V. (2001). Elevation gradients of speciesrichness, historical, and prospective views. Global Ecology and Biogeography, 10, 3-13.

MoAC (2011). District Disaster Risk Management Plan: Arghakhanchi District. Ministry of Agriculture and Co-operatives, Government of Nepal, pp. 101.

O’Brien, E. M. (2002). Water-energy dynamics, climate, and prediction of woody plant species richness: an interim general model. Journal of Biogeography, 25, 379-398.

O’Brien, E. M., Whittaker, R. J., \& Field, R. (1998). Climate and woody plant diversity in southern Africa, relationships at species, genus and family levels. Ecography, 21, 495-509.

Oommen, M. A., \& Shanker, K. (2005). Elevational species richness patterns emerge from multiple local mechanisms in Himalayan woody plants. Ecology, 86(11), 3039-3047.

Panthi, M. P. (2005). Plant Diversity and Resource utilization in Arghakhanchi and Manang district, Central Nepal (PhD thesis). Central Department of Botany, Tribhuvan University, Kirtipur, Nepal.

Panthi, M. P., \& Chaudhary, R. P. (2002). Angiospermic flora of Arghakhanchi district and adjoining areas, west Nepal. Natural History Museum, 21, 7-21.

Pitcher, C. R., Lawton., Ellis, N., \& Smith, S. J. (2012). Exploring the role of environmental variables in shaping patterns of seabed biodiversity composition in regional-scale ecosystems. Journal of Applied Ecology, 49(3), 670-679.

Pokhrel, K. P. (2013). Chure forestry conservation and management plan: A case study of Arghakhanchi district, Nepal. Journal of Geography and Regional Planning, 6(5), 172-183.

Pokharel, K., Basnet, K., Majupuria, T., \& Baniya, C. (2018). Environmental variables of the Seti-Gandaki River basin of Pokhara, Nepal. Journal of Institute of Science and Technology, 22(2), 129-139.

Poudel, S., Bhattarai, N., Yogi, P. N., \& Karmacharya, R. B. (2010). Ethnobotanical plants used by the people of Argha VDC, Arghakhanchi district, west Nepal. Plant Resources (Golden Jubilee, 2066), 32, 73-85.

Rahbek C. (1995). The elevational gradient of species richness, a uniform pattern? Ecography, 18, 200205 .
Rahbek, C. (2005). The role of spatial scale and the perception of large-scale species-richness patterns. Ecology Letters, 8, 224-239.

Rai, R., \& Singh, N. B. (2015). Medico-ethnobiology in Rai community: A case study from Baikunthe village development committee, Bhojpur, Eastern Nepal. Journal of Institute of Science and Technology, 20(1), 127-132.

Rajbhandari. K. R., Rai, S. K., Bhatta, G. D., Chheri, R., \& Khatri, S. (2017). Flowering plants of Nepal: An introduction. Department of Plant Resources, Ministry of Forests and Soil conservation, Government of Nepal, p. 432.

Ramsay, P. M., \& Oxley, E. R. B. (1997). The growth form composition of plant communities in the Ecuadorian paramos. Plant Ecology, 131, 173-192.

Rana, P., Koirala, M., Bhuju, D., \& Boonchird, C. (2016). Population structure of Rhododendron campanulatum D. Don and associated tree species along the elevational gradient of the Manaslu Conservation Area, Nepal. Journal of Institute of Science and Technology, 21(1), 95-102.

R Core Team (2019). R: A language and environment for statistical computing. R Foundation for Statistical Computing, Vienna, Austria. URL. https://www.Rproject.org/.

Sharma, P., Rana, J. C., Devi, U., Randhawa, S. S., \& Kumar, R. (2014). Floristic diversity and distribution patterns of plant communities along the altitudinal gradient in Sangla valley, Northwest Himalaya. The Scientific World Journal, 214, Article ID 264878 (11pp). https://doi.org/10.1155/2014/264878.

Shuai, L. Y., Ren, C. L., Yan, W. B., Song, Y. L., \& Zeng, Z. G. (2017). Different elevational patterns of rodent species richness between the southern and northern slopes of a mountain. doi:10.1038/s41598017-09274-2.

Song, C., \& Cao, M. (2017). Relationships between plant species richness and terrain in middle sub-tropical Eastern China. Forests, 8, 344 (13 pp).

Stevens, G. C. (1989). The latitudinal gradient in geographical range: how so many species exist in tropics. American Naturalists, 133, 240-256.

Stevens, G. C., \& Fox, J. F. (1991). The causes of tree line. Annual Review of Ecology and Systematics, 22, 177-191.

Vetaas, O. R., \& Ferrer-Castan, D. (2008). Pattern of woody plant species richness in the Iberian Peninsula: Environmental range and spatial scale. Journal of Biogeography, 35, 1863-1878. 
Wang, Z. H., Tang, Z. Y., \& Fang, J. Y. (2007). Altitudinal patterns of seed plant richness in the Gaoligong Mountains, South-east Tibet, China. Diversity and Distribution, 13, 845-854.

Webb, T. J., \& Gaston, K. J. (2003). On the heritability of geographic range sizes. American Naturalist, 161, 553-566.

Williams, C. B. (1964). Patterns in the balance of nature and related problems in quantitative ecology. Theoretical and Experimental Biology, 3, pp.324.

Wills, S. C., Winemiller, K. O., \& Lopez-Fernandez, H. (2005). Habitat structural complexity and morphological diversity of fish assemblages in a Neotropical floodplain river. Oecologia, 142, 284295.

Xu, X., Zhang, H., Zhang, D., Tian, W., Huang, H., \& Ma, A. (2017). Altitudinal patterns of plant species richness in the Honghe region of China. Pakistan Journal of Botany, 49(3), 1039-1048.

Yan, H., Liang, C., Li, Z., Liu, Z., Miao, B., He, C., \& Sheng, L. (2015). Impact of precipitation patterns on biomass and species richness of annuals in a dry steppe. PLOS ONE, p. 14 https://doi.org/10.1371/journal.pone.0125300.

Zhang, W., Huang, D., Wang, R., Liu, J., \& Du. N. (2016). Altitudinal patterns of species diversity and phylogenetic diversity across temperate mountain forest of Northern China. PLOS ONE, 11(7), 1-13.

Zhang, X., Wang, H., Wang, R., Wang, Y., \& Liu, J. (2017). Relationships between plant species richness and environmental factors in nature reserves at different spatial scales. Polish Journal of Environmental Studies, 26(5), 2375-2384. DOI: https://doi.org/10.15244/pjoes/69032.

APPENDIX 1. Complete regression of species richness by use of generalized linear model against altitude and climatic variables in Arghakhanchi district $\left(R^{2}=0.64\right.$ to $\left.0.95, p<0.01\right)$

\begin{tabular}{|l|l|l|l|l|l|l|l|l|}
\hline Model & Predictor & Response & $\mathrm{D}_{\mathrm{f}}$ & ResidDev & $\mathrm{D}_{\mathrm{f}}$ & Deviance & $\mathrm{F}$ & $\operatorname{Pr}(\mathrm{F})$ \\
\hline 0 & Altitude & Total species & 22 & 362416 & & & & \\
\hline $\mathbf{2}$ & & & $\mathbf{2 0}$ & $\mathbf{3 2 7}$ & $\mathbf{2}$ & $\mathbf{3 6 2 0 8 8}$ & $\mathbf{1 4 7 8 2}$ & $<\mathbf{2 . 2 e - 1 6}$ \\
\hline 0 & Altitude & Dicot species & 22 & 245523 & & & & \\
\hline $\mathbf{2}$ & & & $\mathbf{2 0}$ & $\mathbf{2 8 0}$ & $\mathbf{2}$ & $\mathbf{2 4 5 2 4 3}$ & $\mathbf{1 1 6 3 4}$ & $<\mathbf{2 . 2 e - 1 6}$ \\
\hline 0 & Altitude & Monocot & 21 & 6213.5 & & & & \\
\hline $\mathbf{2}$ & & & $\mathbf{1 9}$ & $\mathbf{2 7}$ & $\mathbf{2}$ & $\mathbf{6 1 8 6 . 5}$ & $\mathbf{2 4 9 7}$ & $<\mathbf{2 . 2 e - 1 6}$ \\
\hline 0 & Altitude & Gymnosp & 17 & 15.1111 & & & & \\
\hline $\mathbf{2}$ & & & $\mathbf{1 5}$ & $\mathbf{1 . 4 6 0 5}$ & $\mathbf{2}$ & $\mathbf{1 3 . 6 5 1}$ & $\mathbf{7 2 . 2 6 2}$ & $\mathbf{1 . 9 9 3 E - 0 8}$ \\
\hline 0 & Altitude & Ferns species & 21 & 147.818 & & & & \\
\hline $\mathbf{2}$ & & & $\mathbf{1 9}$ & $\mathbf{1 . 9 2}$ & $\mathbf{2}$ & $\mathbf{1 4 5 . 9}$ & $\mathbf{7 9 6 . 3 9}$ & $<\mathbf{2 . 2 e - 1 6}$ \\
\hline 0 & AMT* & Total spp & 21 & 270206 & & & & \\
\hline $\mathbf{2}$ & & & $\mathbf{1 9}$ & $\mathbf{1 7 0}$ & $\mathbf{2}$ & $\mathbf{2 7 0 0 3 6}$ & $\mathbf{1 9 4 6 1}$ & $<\mathbf{2 . 2 e - 1 6}$ \\
\hline 0 & MAR $^{\text {a }}$ & Total spp & 21 & 270206 & & & & \\
\hline $\mathbf{2}$ & & & $\mathbf{1 9}$ & $\mathbf{3 7 6}$ & $\mathbf{2}$ & $\mathbf{2 6 9 8 3 1}$ & $\mathbf{7 1 5 6 . 4}$ & $<\mathbf{2 . 2 e - 1 6}$ \\
\hline
\end{tabular}

*AMT-Annual mean temperature, ${ }^{a}$ MAR - Mean annual rainfall, all bold entries were accepted model 